\title{
ACCOUNTING QUALITY VERSUS AUDITOR CHOICE UNDER STRONG Tax-GAAP CONFORMITY: THE CASE OF BRAZIL
}

\author{
CARLOS MELLO-E-SOUZA \\ Professor Assistant \\ Seatlle University \\ E-mail: carlosms@seatlleu.edu
}

\section{ABSTRACT}

Brazilian companies with a Big 4 auditor have better accounting quality than those with a local auditor, when accounting quality is measured either by compliance with GAAP or by conservatism. However, the cross-sectional pattern of discretionary accruals - often used to measure accounting quality in other countries-is unrelated to quality in Brazil. In fact, companies with Big 4 auditors tend to recognize income more aggressively than companies with a local auditor. This is the opposite of what happens in other countries and it is consistent with local auditors interpreting the tax code (rather than GAAP) more aggressively than Big 4 auditors, due to the strong linkage that exists between the Brazilian tax code and financial reporting standards.

Keywords: Accounting Quality; Auditor Choice; Discretionary Accruals; REFIS; Tax-To-GAAP Conformity.

\section{RESUMO}

As empresas brasileiras com um auditor do grupo das "Big 4" têm melhor qualidade de contabilidade do que aquelas com um auditor local, quando a medição de tal qualidade da contabilidade se dá ou pela aderência aos PCGA ou pelo conservadorismo. Entretanto, a aplicação de um padrão de análise levando em conta as provisões contábeis voluntárias - modelo usado freqüentemente para medir a qualidade da contabilidade em outros paises - não serve para avaliar a qualidade da contabilidade no Brasil. Na verdade, empresas com auditores do grupo das "Big 4" tendem a reconhecer lucros mais agressivamente do que clientes de auditores locais. Isto é o oposto do que se constata em outros países e é consistente com o fato de que os auditores locais interpretam as leis tributárias (e não os PCGA) mais agressivamente do que os auditores do grupo das "Big 4" devido à forte ligação entre a legislação tributária brasileira e as respectivas normas referentes ao preparo de demonstrações financeiras.

Palavras-chave: Qualidade da Contabilidade; Escolha do Auditor; Provisões Contábeis Voluntárias; REFIS; Conformidade entre Normas Tributárias e PCGA. 


\section{INTRODUCTION}

Is it true in Brazil-as it appears to be in many other countries - that companies that hire a Big $4^{1}$ auditor produce better accounting disclosures than companies that hire a local auditor? This question involves more than a replication of similar studies conducted for other countries because of two special features of the Brazilian environment. The first is leniency in the enforcement of generally accepted accounting principles by Brazilian regulatory agencies (La PORTA, LOPEZ-DE-SILANES and SHLEIFER, 1998; PATEL, BALIC and BWAKIRA, 2002.) The second feature is the existence of a strong linkage between the Brazilian tax code and financial reporting principles (HUNG, 2001; Appendix A.)

Leniency does not imply that quality is irrelevant for companies and auditors because alternative mechanisms arise to impose accounting discipline. For example, a higher quality of earnings is associated with lower costs of capital (BOTOSAN, 1997; RICHARDSON and WELKER, 2001; HRIBAR and JENKINS, 2004; and FRANCIS, LaFOND and OLSSON, 2004.) In addition, where enforcement is weak but the GAAP framework is strong, firms may attempt to differentiate themselves in terms of accounting quality by choosing a reputable auditor (HOLTHAUSEN, 2003.) Still, it is an empirical question whether Brazilian firms rely on auditor choice as a signal of quality.
A strong linkage between tax and financial reporting transforms into a serious handicap a common feature of many studies of quality and auditor choice (e.g: JONES, 1991; DECHOW, SLOAN and SWEENEY, 1995): the assumption that Big 4 auditors, because of their large reputation capital and "deep pockets," will try to impose conservative accounting methods (i.e., income reducing accruals), more often than their smaller competitors will. The problem with this assumption, under strong tax-GAAP conformity, is that minimization of income in the financial statements leads to minimization of income in the tax return, and the latter may cause problems with the tax authority. Thus, it is no longer clear whether the Big 4 would prefer income increasing or income decreasing discretionary accruals.

Using a sample of 97 publicly traded firms that adopted the REFIS tax amnesty of 2000, it was found that there is no difference in quality between Big 4 and non-Big 4 auditors if quality is measured by the behavior of discretionary accruals, but significant differences were found in quality using compliance with GAAP and conservatism as indicators of quality. These results support the hypothesis that Brazilian firms use Big 4 auditors as a signal of quality, and show that discretionary accrual behavior is an unreliable indicator of quality under strong tax-GAAP conformity.

\section{MEASURES OF ACCOUNTING QUALITY}

\subsection{Discretionary Accruals}

Accruals can be broken down into discretionary and non-discretionary components. Discretionary accruals, measured by the original or by the modified Jones model (JONES, 1991; DECHOW, SLOAN and SWEENEY, 1995), are often used in studies of quality because they are vulnerable to manipulation. Non-discretionary accruals, being driven by the firm's level of operations, are assumed to be unrelated to quality.

Two measures of accruals were used: total accruals (net income minus operating cash flow ${ }^{2}$ ), and working capital accruals (increase in net working capital excluding short term debt, cash and cash equivalents.) Discretionary total accruals based on the original and modified versions of the Jones model, for company i at year $t$, are denoted respectively as $D T A_{i t}^{1}$ and $D T A_{i t}^{2}$, and are estimated as the error terms in:

$$
T A_{i t}=\alpha_{1 t}\left(1 / A_{i t-1}\right)+\alpha_{2 t} \Delta R E V_{i t}+\alpha_{3 t} P P E_{i t}+\varepsilon_{i t}
$$

and in:

$$
T A_{i t}=\alpha_{1 t}\left(1 / A_{i t-1}\right)+\alpha_{2 t}\left(\Delta R E V_{i t}-\Delta R E C_{i t}\right)+\alpha_{3 t} P P E_{i t}+\varepsilon_{i t}
$$

The following notation is used: ( $i$ is the firm, $t$ is time)

$A_{i t .1}$ total assets at the end of $t-1$;

$T A_{i t}$ total accruals divided by $A_{i t .1}$;

$W K A_{i t}$ working capital accruals, $\Delta C A_{i t}-\Delta C L_{i t}+\Delta S T D_{i t}$ - $\triangle C A S H_{i t}$, divided by $A_{i t-1}$;

$\triangle R E V_{i t}$ revenues during $t$ minus revenues during $t-1$, divided by $A_{\text {it. } 1 \text {; }}$;

$\triangle R E C_{i t}$ receivables at the end of $t$ minus receivables at the end of $t-1$, divided by $A_{i t-1}$;

$P P E_{i t}$ net property plant and equipment divided by $A_{i t-1}$.

Discretionary working capital accruals for both versions of the Jones model are denoted DWKA $A_{i t}^{1}$ and $D W K A_{i t}^{2}$, and are estimated by expressions similar to [1] and [2], but with $W K A_{i t}$ replacing $T A_{i t}$ on the left-hand side and without the PPE term on the right-hand side.

\footnotetext{
1 Throughout this paper it was used the current "Big 4" terminology, even though in 2000 there were still five large multinational accounting firms: Andersen, Deloitte, Ernst E Young, KPMG, and PricewaterhouseCoopers.

2 cash flow from operations as funds from operations have been computed (as published under Brazilian GAAP) minus working capital accruals, interest expense and inflationary adjustments.
} 


\subsection{Compliance with GAAP}

The second indicator of accounting quality is compliance with GAAP. In particular, it was observed the degree to which listed companies that accepted the REFIS tax amnesty of 2000 complied with reporting requirements of the Brazilian Securities Commission (CVM). The CVM's rules for the amnesty - Instruction No. 346 (of 09/2000) —are clear and the amnesty's impact on most acceptors was significant, which means that involuntary errors and omissions should be rare and lack-of-materiality should not be a common reason for avoiding disclosure.

A key requirement of I\#346 was for companies to disclose the net benefit from the amnesty as an extraordinary item and to provide a detailed breakdown of the benefit in footnotes. The gain attributable to the amnesty can be traced to penalties waived, previously unrecognized tax assets or liabilities and discounts on net operating loss carry forwards acquired. (Table 2, Panel B, contains a summary of I\#346.)

The information content of the disclosures required by I\#346 is not uniform. For example, item A (the impact of the amnesty on income) is a key input for estimating the value of securities issued by each company. However, the information provided in items $\mathrm{E}$ though $\mathrm{H}$ can be obtained easily from other sources or estimated by investors. Since the quality implications of not complying with any given item in I\#346 depends on that item's relevance to decision making by investors, two subsets of disclosures were considered: items needed and items not needed for decision making by investors.

To assess compliance with I\#346 management's discussion and analysis, the auditor's letter, financial statements, and footnotes included in year 2000 financial reports for all publicly traded companies that accepted the amnesty were consultedand it was checked whether these companies complied in full, partially, or not at all with the mandatory requirements of I\#346. It was assigned to each company 100 points in the first case, 50 in the second, and zero in the third. Finally, a company's decision-making and overall scores as the ratio of points assigned divided by the maximum points available in each category was computed, expressed as a percentage.

\subsection{Conservatism}

The third indicator of accounting quality is conservatism, defined as timely recognition of contingent losses. Accrual of contingencies can be used as a measure of quality in Brazil because they do not generate a deductible expense for tax purposes. Conservatism was measured using evidence regarding liabilities that were revealed for the first time in December of 2000 - when companies joined the amnestythat probably should have been disclosed before.

Companies that accepted the amnesty were committed to paying a reduced liability over an extended period of time at below market interest rates. Prior to accepting the amnesty, these companies were disputing the claim that taxes were overdue and they could have continued to do so had they rejected the amnesty. It was assumed that companies that accepted the amnesty weighed the expected liability value of rejecting the amnesty against the expected value of accepting the amnesty, and found the former to be greater.

According to Brazilian GAAP, the need and the format for disclosing contingent liabilities depends on the anticipated probability of loss. ${ }^{3}$ There are three cases: remote contingencies need not be disclosed; reasonably possible contingencies must be disclosed but not accrued; and probable contingencies must be described in footnotes and accrued if their values can be estimated. Brazilian standards are not precise about numerical probability thresholds for these three categories. Therefore, past due taxes included in the amnesty program could be in one of four possible conditions before December of 2000: (1) disclosed on the balance sheet as part of an installment agreement; (2) disclosed on the balance sheet as a probable contingent liability; (3) disclosed in the footnotes as a reasonably possible contingent liability; or (4) they could be undisclosed. It was assume that all category (4) liabilities included in the amnesty were in violation of GAAP and should have been at least mentioned in footnotes by December of 1999. If perceived probability thresholds in Brazil are similar to those in the U.S., this is equivalent to assuming that all previously undisclosed liabilities included in the amnesty had loss probabilities equal to or greater than $25 \%$, the highest estimate of the remote/reasonably possible threshold in the U.S. (RAGHUNANDAN et al., 1991; REIMERS, 1992; AHARONY and DOTAN, 2004.)

\section{DATA AND DESCRIPTIVE STATISTICS}

In 2000 there were 769 listed companies in Brazil according to the CVM's website (http://www.cvm.gov.br/). Of these, 224 are eliminated for being government-controlled or classified as utilities or financial institutions. Another 148 are eliminated for the following reasons: 77 reported zero revenues in 2000; 38 had trading in their securities suspended; 3 were not operating or reported zero net income in 1999-2000; 11 were bankrupt; and 19 did not file financial reports for 2000 . For each of the remaining 398 companies it was obtained financial statements for 1999 and 2000, and also management's discussion and analysis, footnotes, and the auditor's letter for 2000 . Of those 398 companies, 97 joined the tax amnesty of 2000. 
In order to estimate discretionary accruals information on funds generated by operations was needed. In 1999 and 2000, 108 and 86 respectively of the remaining 398 companies in the sample did not file, or filed incomplete funds flow statements. This reduces the effective sample size for estimation of discretionary accruals to 290 in 1999 and to 312 in 2000. In the sample used to estimate discretionary accruals in 2000, most firms are engaged in manufacturing activities, the proportions being $64 \%$ in the full sample and $72 \%$ in the amnesty sub-sample. About $57 \%$ of firms in the full sample are audited by one of the Big 4 , but only $38 \%$ in the amnesty sub-sample. In terms of exchange listing, a higher percentage of companies that choose a Big 4 auditor are listed on Bovespa and/or a U.S. exchange (72\%) than companies that choose otherwise (65\%).

Table 1 contrasts median values of total and working capital discretionary accruals, size, asset turnover, leverage and profitability according to auditor choice in 1999-2000. There are significant differences in discretionary accruals measured by the modified Jones model $\left(D T A^{2}\right.$ and $\left.D W K A^{2}\right)$ in 1999 - when firms with a Big 4 auditor tend to post less income-decreasing accruals. There are no significant differences in discretionary accruals in 2000. Firms with a Big 4 auditor are consistently larger based on mean and median total assets, and more profitable based on the median ratio of operating profits to sales. There is also indication in 2000 that firms with a Big 4 auditor carry less debt, based on the median ratio of liabilities to total assets.

Table 2, Panel A contains compliance statistics for each item in I\#346. The first column describes the disclosure, the second column has the number of firms in the sample that should have provided that disclosure, and the last three columns have the percentages of firms that complied in full, partially, or not at all. The percentage of firms that completely ignored each disclosure requirement varies from $3.3 \%$ to $90.6 \%$, with $44.3 \%$ of the 97 acceptors providing no information at all about the impact of the amnesty on income (item A). Another indicator of poor compliance is that, although all 74 firms that chose to pay the amnesty over a variable term were required to disclose the present value of the liability (item $\mathrm{H}$ ), only $8.1 \%$ complied in full, $18.9 \%$ provided some information, and $73 \%$ provided no information regarding the present value of the liability. Of the 97 amnesty companies, only 40 provided sufficient information to allow estimation of the values of accepting and rejecting the amnesty. These are the companies for which the third measure of accounting quality (conservatism) can be evaluated: 40 of these companies achieved an average decision-making score of 69.8 versus 28.1 for the remaining 57 companies.

In order to verify the degree to which the CVM enforced I\#346, "Market Alert/Rectify and Republish Actions" (since 06/2001) and "Decisions of the CVM's Collegiate in Appeals Processes" (since 08/2000) on the CVM's website were consulted. ${ }^{4}$ Most, if not all disciplinary actions taken by the CVM regarding annual reports for fiscal 2000 should be included in one of these two archives. Of the 97 firms in the sample of amnesty acceptors, only three were ordered by the CVM to republish year 2000 financial statements due to violations of I\#346. ${ }^{5}$ This is consistent with the generally low rankings achieved by Brazil in international comparisons of GAAP enforcement (La PORTA, LOPEZ-DE-SILANES and SHLEIFER, 1998; PATEL, BALIC and BWAKIRA, 2002.)

Table 3 contains a breakdown of amnesty liabilities for this group of 40 acceptors. The breakdown is according to whether, prior to the amnesty, liabilities had been recognized as payable on the balance sheet (P-type), contingent on the balance sheet or in the notes (C-type), or unrecognized (U-type). The fractions of the aggregate amnesty liability that had been recognized as $\mathrm{P}, \mathrm{C}$, and $\mathrm{U}$ were $40 \%, 10 \%$ and $50 \%$ respectively. The fraction of unrecognized liabilities is higher for the 18 companies with a local auditor $(68 \%)$ than for the 22 companies with a Big 4 auditor (40\%).

\section{STATISTICAL TESTS AND DISCUSSION OF RESULTS}

\subsection{Discretionary Accruals}

If discretionary accruals were driven mostly by earnings manipulation motives it would be expected that companies with a Big 4 auditor display more income-reducing discretionary accruals than companies with a local auditor. The study showed that the opposite would be expected, however, if accruals are heavily influenced by tax minimization motives. Although it is a priori unknown which of these two motives dominates in Brazil (where tax-to-GAAP conformity is strong), it is worthwhile to observe the pattern of discretionary accruals as a function of auditor choice. If we can assume that Big 4 audits produce higher quality financial disclosures, and companies audited by the Big 4 have less income-decreasing discretionary accruals, then we can conclude that the Big 4 are less tolerant of aggressive tax minimization strategies.

It was measured the association between auditor choice on total discretionary accruals by means of the following linear regression model, estimated for 1999 and 2000:

\footnotetext{
4 The CVM's powers to prescribe accounting standards and to require rectification of financial reports are established by Law $6385 / 1976$. The penalties that the CVM can impose when accounting standards are violated range from warnings and fines to a 20 -year prohibition from holding executive positions in listed companies

5 Wetzel was required to republish its 2001 and 2002 reports to shareholders. Sultepa and Josapar were required to republish their 2000 reports. The case of Sultepa was the most serious, given an overall compliance score of only $12.5 \%$, and an amnesty liability equivalent to about $20 \%$ of total liabilities. Three other acceptors had worse compliance scores and more material amnesty liabilities than Sultepa, but were not required to republish any reports.
} 
$D T A_{i}^{k}=\beta_{0}+\beta_{1} A U D_{i}+\beta_{2} L S T_{i}+\beta_{3} H I L E V_{i}+\beta_{4} N E G S E_{i}+\beta_{5} S I Z_{i}+\beta_{6} L A B T A_{i}+\varepsilon_{i}$

where $i$ is a firm index, and:

$D T A_{i}^{k}$ discretionary total accruals obtained with the original $(k=1)$ and modified $(k=2)$ versions of the Jones model;

AUD ${ }_{i}$ auditor choice, 1 if auditor is Big 4 (AA, DT, EY, KPMG, PWC in 2000), 0 otherwise;

LST $_{i}$ listing choice, 1 if firm is listed on Bovespa or any U.S. exchange, 0 otherwise;

HILEV $_{i}$ indicator of very high leverage, 1 if the company is in the highest decile according to the ratio of debt to total assets at year-end, 0 otherwise;

NECSE indicator of negative shareholders' equity, 1 if shareholders' equity is negative at year-end, 0 otherwise;

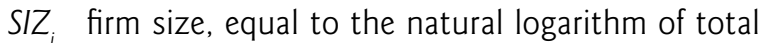
assets at year-end;

$\angle A B T A_{\text {, }}$ magnitude of accruals, equal to the natural logarithm of absolute total accruals;

Model [3] is similar to the model used in (BECKER et al., 1998), except that two variables were dropped - change in shares outstanding and change in auditor-due to data collection costs, and it was added the choice of exchange listing and negative shareholders' equity variables. High leverage can be associated with income-increasing accruals, in the case of firms that are close to violating debt covenants, or to income-decreasing accruals, in the case of distressed companies (DeFOND and JIAMBALVO, 1994). Negative shareholders' equity is introduced as an additional control for highly distressed companies. Since companies audited by the Big 4 are on average larger than companies with local auditors by value of total assets (Table 1), and size can proxy for omitted variables, the natural log of total assets is included. The last variable is magnitude of accruals, because of the possibility that large dis- cretionary accruals are associated with large total accruals. (There is some indication in Table 1 that, in 2000, working capital accruals are greater for the Big 4.)

To examine the association between auditor choice and working capital discretionary accruals, $D W K A^{k}$, was substituted on the left-hand side, and $\angle A B T A_{i}$ was replaced by the log of absolute working capital accruals on the righthand side.

Results for 1999 and 2000 are given in Table 4. In general, if discretionary accruals are determined by the original Jones model, it cannot be rejected the null hypothesis that auditor choice is unrelated to discretionary accruals in 1999 or in 2000. Switching to the modified Jones model, it still cannot reject the null in 2000 , but it does reject it in 1999. In 1999 the coefficient of AUD is positive in the models of total accruals $\left(D T A^{2}\right)$ and working capital accruals $\left(D W K A^{2}\right)$, implying that the expected value of discretionary accruals conditional on choosing a Big 4 auditor is greater (i.e., more income-increasing) than if a local auditor is chosen.

These results imply that tests based on discretionary accruals fail to discriminate accounting quality in Brazil in 1999-2000. If audit quality and accounting quality are related -in the sense that Big 4 auditors would engage in less income-increasing accruals than local auditors if there were no tax constraints on financial reporting - and if the true coefficient of AUD is on average positive over time for the modified Jones model, the implication is that Big 4 auditors tolerate a less aggressive interpretation of the tax code than local auditors.

\subsection{Compliance with GAAP}

To test whether compliance with I\#346 is affected by auditor and exchange listing choices, it was estimated the following cross-sectional regression model:

$$
C S C R_{i}=\beta_{0}+\beta_{1} A U D_{i}+\beta_{2} L S T_{i}+\beta_{3} H I L E V_{i}+\beta_{4} N E G S E_{i}+\beta_{5} S I Z_{i}+\beta_{6} C O N_{i}+\varepsilon_{i}
$$

where $i$ is a firm index, and:

$\mathrm{CSCR}_{i}$ compliance score with I\#346, measured by the ratio of points obtained to maximum possible decision making points (or overall points), expressed as a percentage,

$\mathrm{CON}_{i}$ concentration of control, measured by percentage of common and preferred shares owned by controlling shareholders, and the other variables are as defined before.

Compliance to be positively related with the choices of a Big 4 auditor and with the decision to list on Bovespa or on a U.S. exchange is expected. It is also expected that this association be stronger when compliance refers to the decision-making items (more relevant disclosures to investors), than when compliance refers to absolutely all items of the CVM's instruction. The regression model includes four other variables. Indicators for high leverage and for negative shareholders' equity, as well as a measure of size, are included for consistency with model [3]. Risk and size proxy for reputation at stake and other potentially omitted variables (BECKER et al., 1998). The fourth variable is concentration of control, which allows for the possibility that firms with concentrated ownership produce better disclosures (DeFOND and JIAMBALVO, 1991). ${ }^{6}$

Table 5, Panel $A$, shows the results of estimating model [4] with OLS for the decision-making and for the overall compliance scores. With the decision-making score as the

6 It was not used the concentration of control variable in model [3] due to data collection constraints. 
dependent variable the null hypothesis $\left(H_{0}\right)$ that accounting quality is either unrelated to auditor choice or worse for Big 4 auditors is rejected, in favor of the alternative that quality is better for companies with a Big 4 auditor ( $p=$ .025). With the overall compliance score as the dependent variable it can only be rejected $H_{0}$ at or above the $5.4 \%$ level of significance. The stronger result for auditor choice when the decision-making score is used as a measure of accounting quality is consistent with a heavier emphasis by auditors on disclosures that are relevant for capital allocation decisions. The $\mathrm{p}$-values for exchange listing choice are about.003 for both measures of compliance.

\subsection{Timeliness of Loss Recognition}

The model for timeliness versus auditor and exchange listing choices is:

$$
T I M_{i}=\beta_{0}+\beta_{1} A U D_{i}+\beta_{2} L S T_{i}+\beta_{3} H I L E V_{i}+\beta_{4} N E G S E_{i}+\beta_{5} S I Z_{i}+\beta_{6} C O N_{i}+\varepsilon_{i}
$$

where $i$ is a firm index, and:

TIM $M_{i}$ timeliness (compliance with GAAP for contingencies) measured by the negative of the ratio of previously undisclosed tax liabilities to all tax liabilities, and the other variables are as defined before. It was expected timeliness to be positively related with the choices of a Big 4 auditor and with the decision to list on Bovespa or on a U.S. exchange. The other independent variables are the same as in model [4], and are included for similar reasons.
Table 5, Panel B, has the results of estimating model [5] with OLS, which led to rejecting the hypothesis that timeliness is unrelated to auditor choice, or worse for Big 4 auditors, in favor of the alternative that timeliness is better for companies with a Big 4 auditor $(p-.041)$. It cannot be rejected, however, the hypothesis that timeliness is unrelated to choice of exchange listing.

\section{CONCLUSION}

In this paper it was examined how publicly traded Brazilian companies that accepted a national tax amnesty in 2000 complied with the CVM's disclosure requirements for the amnesty and for contingent liabilities. Based on these observations it was concluded that Brazilian companies with a Big 4 auditor have better accounting quality than those with a local auditor when accounting quality is measured by compliance with GAAP or by conservatism. This result supports Holthausen's (2003) conjecture that companies attempt to signal accounting quality by means of auditor choice in countries with good accounting principles but lenient enforcement of those principles.
However, the cross-sectional pattern of discretionary accruals-often used to measure quality in other countries - is unrelated to quality in Brazil. In fact, companies with Big 4 auditors in Brazil tend to recognize income more aggressively than companies with a local auditor. This is the opposite of what happens in other countries and it is consistent with local auditors interpreting the tax code (rather than GAAP) more aggressively than Big 4 auditors due to the strong linkage that exists between the Brazilian tax code and financial reporting standards. 


\section{APPENDIX A}

Tax-to-GAAP Conformity in Brazil in $\mathbf{2 0 0 0}$

To determine degree of financial-tax conformity in Brazil in 2000, Hung's (2001) method was used, according to which tax-to-GAAP conformity is high if the combined score from the six items below is positive; otherwise, conformity is low.

1. Consensus estimate of tax-to-GAAP conformity: Strong-1; Moderate/Significant- $1 / 2$; Weak-0

This estimate is not available for Brazil.

2. Are deferred taxes recognized? No-1; Limited-1/2; Yes-0

Yes, according to CVM (Comissão de Valores Mobiliários) Instruction No. 273, NBCT (Normas Brasileiras de Contabilidade) 19.2, and RIR (Regulamento do Imposto de Renda) art. 247-251.

3. Does legal form dominate substance? Yes-1; Sometimes $-1 / 2$; No-0

Ernst $\varepsilon$ Young (2002) reports on the ability of tax authorities in Latin America to challenge transactions based on economic substance. EEY reports that Brazil has historically applied a form over substance approach, but a new law passed in January 2001 will allow authorities to disregard transactions created with the sole purpose of minimizing taxation. Since these developments occurred after the time period studied, the answer is yes.

4. Is additional accelerated depreciation allowed? Yes1; Limited-1/2; No-0

Additional accelerated depreciation means methods other than declining balance or sum-of-years digits. There are two forms of accelerated depreciation in Brazil. According to articles, 313-323 of the tax code (RIR) firms can depreciate at straight-line rates above the usual rates for a variety of special cases in which the government wants to encourage investment. Although the increase in depre- ciation expense caused by this method is tax deductible, it cannot be recognized in the financial statements, and therefore leads to deferred tax liabilities (i.e., no tax-to-GAAP linkage). According to article 312 of RIR, firms that work for a single daily 8-hour shift must apply standard straightline rates; firms that work two shifts can apply $150 \%$ of the standard rates; and firms that work three shifts can apply $200 \%$ of the standard rates. These increases in depreciation expense must be recognized in the books, are not equivalent to any of the traditional depreciation methods, and are deductible for tax purposes. In this case, there is a linkage between tax and financial reporting. Therefore, yes.

5. Do amortization periods depend on tax laws? Yes1; Limited-1/2; No-0

According to article 327 of RIR the minimum is 5 years, which is reflected in IBRACON (Instituto Brasileiro de Contadores) Statement VIII.

6. Does lease capitalization depend on tax laws? Yes1; Limited-1/2; No-0

Article 415 of RIR establishes criteria for capital leases. Brazilian GAAP in 2000 do not differentiate between capital and operating leases, requiring only that the asset and liability effects of capitalizing the lease be shown as a footnote. Therefore, item 6 is not applicable.

The combined score is greater than zero, which implies a high degree of tax-GAAP conformity. Additional supporting evidence includes: depreciation rates used in financial reports are stipulated in the tax code; LIFO is never used, because it is not acceptable for tax purposes; and the amortization period for RED assets is based on the tax code (KPMG, 2001). 
Tabela 1 || Sample Descriptive Statistics by Auditor Type in 1999-2000

\begin{tabular}{|c|c|c|c|c|c|c|c|c|}
\hline & & \multicolumn{3}{|c|}{ Medians } & \multicolumn{3}{|c|}{ Means } & \\
\hline & & (a) & (b) & test $a=b$ & (c) & (d) & test $c=d$ & \\
\hline & & Local & Big 4 & K-W & Local & Big 4 & 2-tailed $t$ & \\
\hline & & & & p-value & & & p-value & \\
\hline 1999 & & $N=129$ & $N=161$ & & $\mathrm{~N}=129$ & $N=161$ & & \\
\hline$D_{T A}^{1}$ & $\%$ & .44 & -.10 & .831 & -2.42 & 1.33 & .217 & \\
\hline$D T A^{2}$ & $\%$ & -.65 & 1.86 & .130 & -4.39 & 2.42 & .025 & * \\
\hline$D W K A^{1}$ & $\%$ & -1.24 & -.54 & .271 & -3.33 & .76 & .115 & \\
\hline$D W K A^{2}$ & $\%$ & -1.02 & -.09 & .023 & -4.82 & 1.25 & .015 & $* * *$ \\
\hline $\operatorname{Abs}\left(D T A^{1}\right)$ & $\%$ & 9.69 & 7.49 & .074 & 14.56 & 12.43 & .410 & \\
\hline $\operatorname{Abs}\left(D T A^{2}\right)$ & $\%$ & 6.68 & 6.08 & .909 & 12.61 & 11.96 & .807 & \\
\hline $\operatorname{Abs}\left(D W K A^{1}\right)$ & $\%$ & 7.73 & 4.79 & .113 & 11.30 & 8.96 & .310 & \\
\hline $\operatorname{Abs}\left(D W K A^{2}\right)$ & $\%$ & 4.35 & 3.52 & .594 & 9.16 & 7.83 & .568 & \\
\hline TA & $\mathrm{R} \$$ mill & 93.2 & 427.8 & .000 & 500.1 & $1,162.1$ & .013 & $\star * \star$ \\
\hline ATO & $x$ & .62 & .69 & .173 & .72 & .77 & .461 & \\
\hline TL/TA & $\%$ & 69.1 & 59.2 & .106 & 90.6 & 72.9 & .208 & \\
\hline Oplnc/Sales & $\%$ & -4.05 & .79 & .012 & -481.00 & -14.43 & .326 & * \\
\hline 2000 & & $N=132$ & $N=180$ & & $N=132$ & $N=180$ & & \\
\hline$D_{T A}^{1}$ & $\%$ & -.42 & -.18 & .653 & -.71 & -.15 & .807 & \\
\hline$D T A^{2}$ & $\%$ & 1.34 & -.38 & .153 & 1.11 & -.92 & .361 & \\
\hline$D W K A^{1}$ & $\%$ & 1.23 & 2.47 & .496 & 2.39 & 3.44 & .613 & \\
\hline$D W K A^{2}$ & $\%$ & 2.01 & .98 & .263 & 2.75 & 1.63 & .574 & \\
\hline $\operatorname{Abs}\left(D T A^{1}\right)$ & $\%$ & 6.96 & 5.76 & .183 & 12.67 & 10.11 & .168 & \\
\hline $\operatorname{Abs}\left(D T A^{2}\right)$ & $\%$ & 6.36 & 4.94 & .031 & 12.20 & 8.63 & .054 & * \\
\hline $\operatorname{Abs}\left(D W K A^{1}\right)$ & $\%$ & 6.27 & 5.33 & .144 & 11.49 & 8.70 & .111 & \\
\hline $\operatorname{Abs}\left(D W K A^{2}\right)$ & $\%$ & 5.57 & 3.70 & .003 & 10.89 & 6.97 & .021 & $* * *$ \\
\hline TA & $\mathrm{R} \$$ mill & 97.9 & 504.7 & .000 & 376.1 & $1,342.8$ & .000 & $* * *$ \\
\hline ATO & $x$ & .60 & .73 & .031 & .67 & .81 & .031 & $* * *$ \\
\hline TL/TA & $\%$ & 71.1 & 61.6 & .025 & 99.7 & 84.8 & .495 & * \\
\hline Oplnc/Sales & $\%$ & .10 & 3.51 & .001 & -47.90 & -15.30 & .206 & * \\
\hline
\end{tabular}

The sample consists of 290 firm observations in 1999 and 312 firm observations in 2000. The data is obtained from the CVM's website. Government-controlled firms, utilities and financial institutions, as well as firms that were suspended from trading, bankrupt, did not file a funds flow statement, or were not operating at the end of 2000 are excluded. Means and medians are given for discretionary accruals, the magnitude of discretionary accruals, total assets, asset turnover, leverage, and profitability. The hypothesis that the medians (means) of firms with Big 4 or local auditors are equal is verified with the Kruskall-Wallis test (2-tailed $\mathrm{t}$ test). "***" indicates that both null hypothesis (of equal means and medians are rejected). "*" indicates that one of the hypothesis is rejected, but not the other.

\section{Notation:}

$D T A^{k}$ - discretionary total accruals per original $(k=1)$ and modified $(k=2)$ Jones models; $D W K A^{k}$ - discretionary working capital accruals per original and modified Jones models;

$$
\text { TA - total assets at year-end; }
$$

ATO - asset turnover, defined as sales divided by total assets at year-end;

TL/TA - leverage, defined as total liabilities divided by total assets at year-end;

Oplnc/Sales -income from continuing operations before tax and before extraordinary items divided by sales. 
Tabela 2 - Compliance with I\#346 by Listed Companies that Accepted the Amnesty

Panel A: Average Disclosure Scores for Mandatory Items in CVM's Instruction No. 346

\begin{tabular}{c|c|c|c|c}
\hline$\downarrow \quad$ (Items marked * contrinute to decision-making score) & $\mathbf{N}$ & Full & Partial & Not at All \\
$*$ A disclose the impact of amnesty on income & 97 & $25.8 \%$ & $29.9 \%$ & $44.3 \%$ \\
\hline Ba loss due to lower rate allowed on NOL carryforwards & 16 & $25.0 \%$ & $68.8 \%$ & $6.3 \%$ \\
\hline Bb gain from recognition of previously unrecognized tax credits & 30 & $63.3 \%$ & $33.3 \%$ & $3.3 \%$ \\
\hline$*$ BC gain on acquisition of NOL's & 19 & $26.3 \%$ & $52.6 \%$ & $21.1 \%$ \\
\hline Bd gain or loss from "consolidation" of liabilities & - & - & - & - \\
\hline$*$ C explain liability according to origin and nature & 97 & $55.7 \%$ & $30.9 \%$ & $13.4 \%$ \\
\hline$*$ D disclose NOL's used to offset interest and penalties & 68 & $52.9 \%$ & $17.6 \%$ & $29.4 \%$ \\
\hline E describe collateral offered & 96 & $26.0 \%$ & $27.1 \%$ & $46.9 \%$ \\
\hline F disclose circumstances and risks of exclusion from amnesty & 96 & $5.2 \%$ & $4.2 \%$ & $90.6 \%$ \\
\hline G list the obligations implied by acceptance of amnesty & 96 & $14.6 \%$ & $19.8 \%$ & $65.6 \%$ \\
\hline H disclose PV of amnesty debt and underlying assumptions & 74 & $8.1 \%$ & $18.9 \%$ & $73.0 \%$ \\
\hline$* \quad$ I report the amounts paid to amortize the amnesty debt & 74 & $66.2 \%$ & $4.1 \%$ & $29.7 \%$
\end{tabular}

\begin{tabular}{|c|c|c|c|}
\hline & Panel B: Instruction No. 346 by the Brazilian Securities Commission (CVM) & Disclosure & I\#346 \\
\hline \multicolumn{4}{|c|}{ A through $\mathrm{G}$ apply to all companies that joined the amnesty } \\
\hline A & Disclose the amnesty's impact separately on the income statement. & $1 / S$ & Art 1, §। \\
\hline B & Explain the amnesty's impact on income by means of its components. & Notes & Art 1, §। \\
\hline C & $\begin{array}{l}\text { Explain the amnesty liability according to origin (type of tax) and nature (principal, interest and penal- } \\
\text { ties). }\end{array}$ & Notes & Art 3, (a) \\
\hline D & $\begin{array}{l}\text { Provide the amounts of tax credits and net operating loss carryforwards used to offset interest and } \\
\text { penalties. }\end{array}$ & Notes & Art 3, (c) \\
\hline $\mathrm{E}$ & Describe the collateral offered to cover the amnesty liability. & Notes & Art 3, (f) \\
\hline $\mathrm{F}$ & Disclose significant risks of exclusion from the amnesty. & Notes & Art 3, (h) \\
\hline G & List the obligations implied by the acceptance of the amnesty. & Notes & Art 3, (g) \\
\hline \multicolumn{4}{|c|}{$\mathrm{H}$ and I apply only to companies that choose the standard payment method } \\
\hline $\mathrm{H}$ & $\begin{array}{l}\text { Disclose present value of the amnesty liability and assumptions used to compute it. Present value } \\
\text { calculations must be revised whenever there is a significant change in the premises adopted, or at } \\
\text { least once a year. }\end{array}$ & Notes & Art 3, (b) \\
\hline I & Disclose amounts paid towards the amnesty during the fiscal period. & Notes & Art 3, (d) \\
\hline \multicolumn{4}{|c|}{ Item $J$ is allowed, but not required, of companies that choose the standard payment method } \\
\hline J & $\begin{array}{l}\text { If (i) the company can meet its amnesty obligations; (ii) assumptions used for present value have been } \\
\text { approved by the board and auditors; and (iii) the discount rate used is appropriate, then the amnesty } \\
\text { liability can be recorded at its present value. The difference between the discounted and undiscounted } \\
\text { values of the liability must be deferred and recognized gradually as income as the debt is paid off. }\end{array}$ & $B / S$ & Art $1, \S \|$ \\
\hline
\end{tabular}

Panel A: Scores are assigned depending on the degree to which companies complied with requirements of I\#346 listed on the left. Items marked * are needed to estimate the values of accepting and rejecting the amnesty, and contribute to the decision-making score. The overall score covers all disclosure items dictated by I\#346. The column titled $N$ shows the number of companies in the sample that should have provided each disclosure in their 2000 annual reports to shareholders. The next three columns contain the percentages of the $N$ companies that complied in full, partially, and not at all with each requirement.

Panel B: The amnesty's effects must be disclosed (and recorded) in the quarter when the decision to accept the amnesty is made. A "fato relevante" advisory to the market is required. 
Tabela 3 - Undisclosed, Contingent and Payable Taxes as of Year-End 1999 for Companies that Accepted the Tax Amnesty of 2000

\begin{tabular}{l|c|c|c|r|r|r|r|c}
\multirow{2}{*}{ By Auditor Choice: } & & \multicolumn{5}{|c|}{ R\$ Millions } & \multicolumn{3}{c}{ Fractions of Total } \\
\cline { 2 - 10 } & $\mathbf{N}$ & $\mathbf{P}$ & \multicolumn{1}{c|}{$\mathbf{C}$} & $\mathbf{U}$ & \multicolumn{1}{c}{ Total } & $\mathbf{P}$ & $\mathbf{C}$ & $\mathbf{U}$ \\
AA & $\mathbf{1 1}$ & 861 & 115 & 811 & 1,788 & .48 & .06 & .45 \\
\hline DT & $\mathbf{1}$ & - & 38 & 23 & 61 & - & .62 & .38 \\
\hline EY & $\mathbf{4}$ & 104 & 117 & -1 & 219 & .47 & .53 & - \\
\hline KPMG & $\mathbf{1}$ & - & 10 & -3 & 7 & - & 1.00 & - \\
\hline PWC & $\mathbf{5}$ & 91 & 41 & 102 & 234 & .39 & .17 & .44 \\
\hline Big 4 auditors & $\mathbf{2 2}$ & 1,056 & 321 & 932 & 2,309 & .46 & .14 & .40 \\
\hline LOcal auditors & $\mathbf{1 8}$ & 364 & 37 & 839 & 1,240 & .29 & .03 & .68 \\
\hline TOTAL & $\mathbf{4 0}$ & 1,420 & 358 & 1,771 & 3,549 & .40 & .10 & .50
\end{tabular}

Breakdown of the total amnesty liability by auditor type and according to whether, prior to the amnesty (i,e., by year-end 1999), the liabilities that these companies included in the amnesty were: [P-type] recognized as payable on the balance sheet; [C-type] recognized as contingent either on the balance sheet or in the notes to the financial statements; or [U-type] absolutely undisclosed. The 40 companies represented in this table are those that provided sufficient information in the 2000 annual report for the estimation of the values of accepting and rejecting the amnesty. 


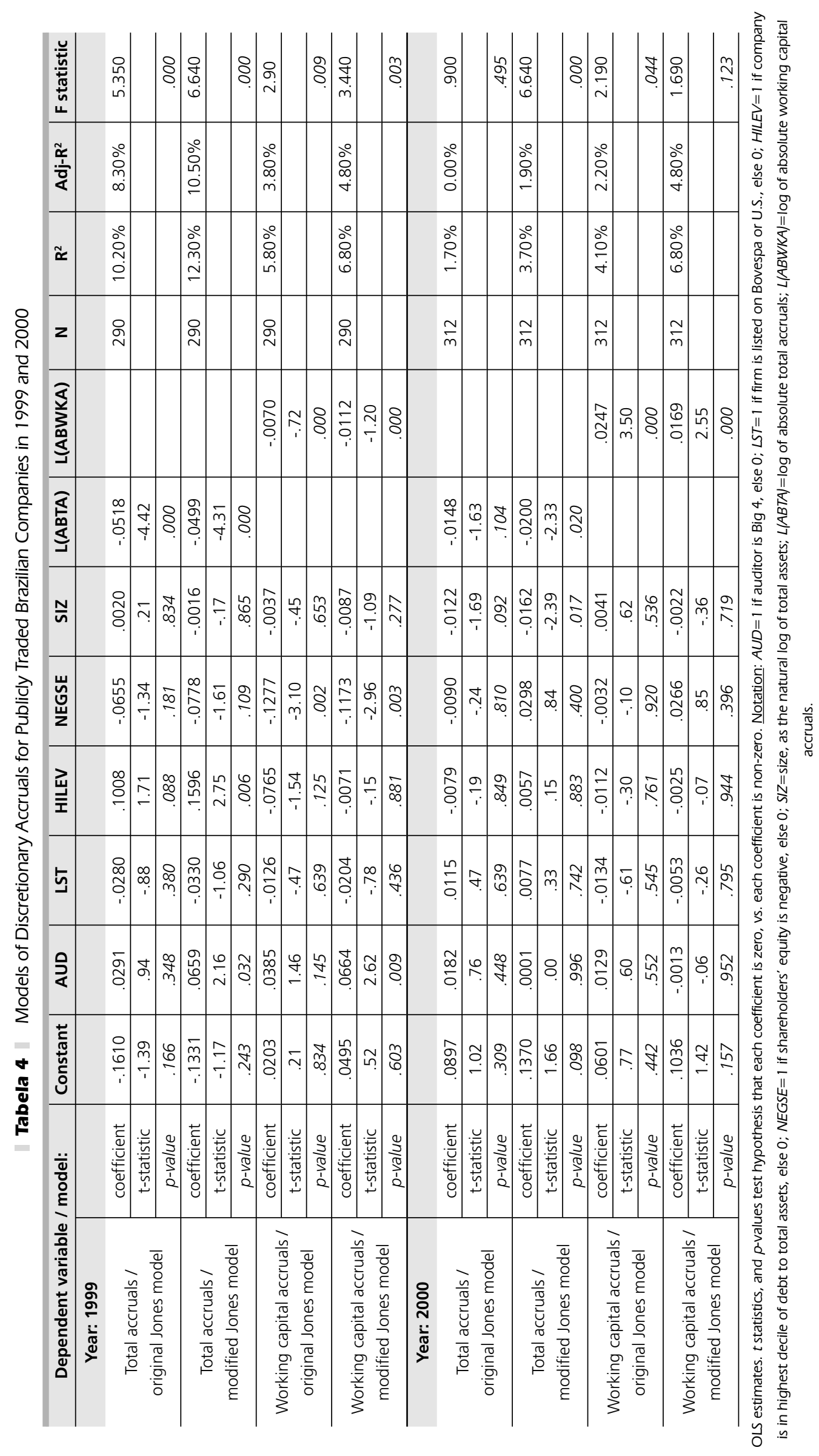



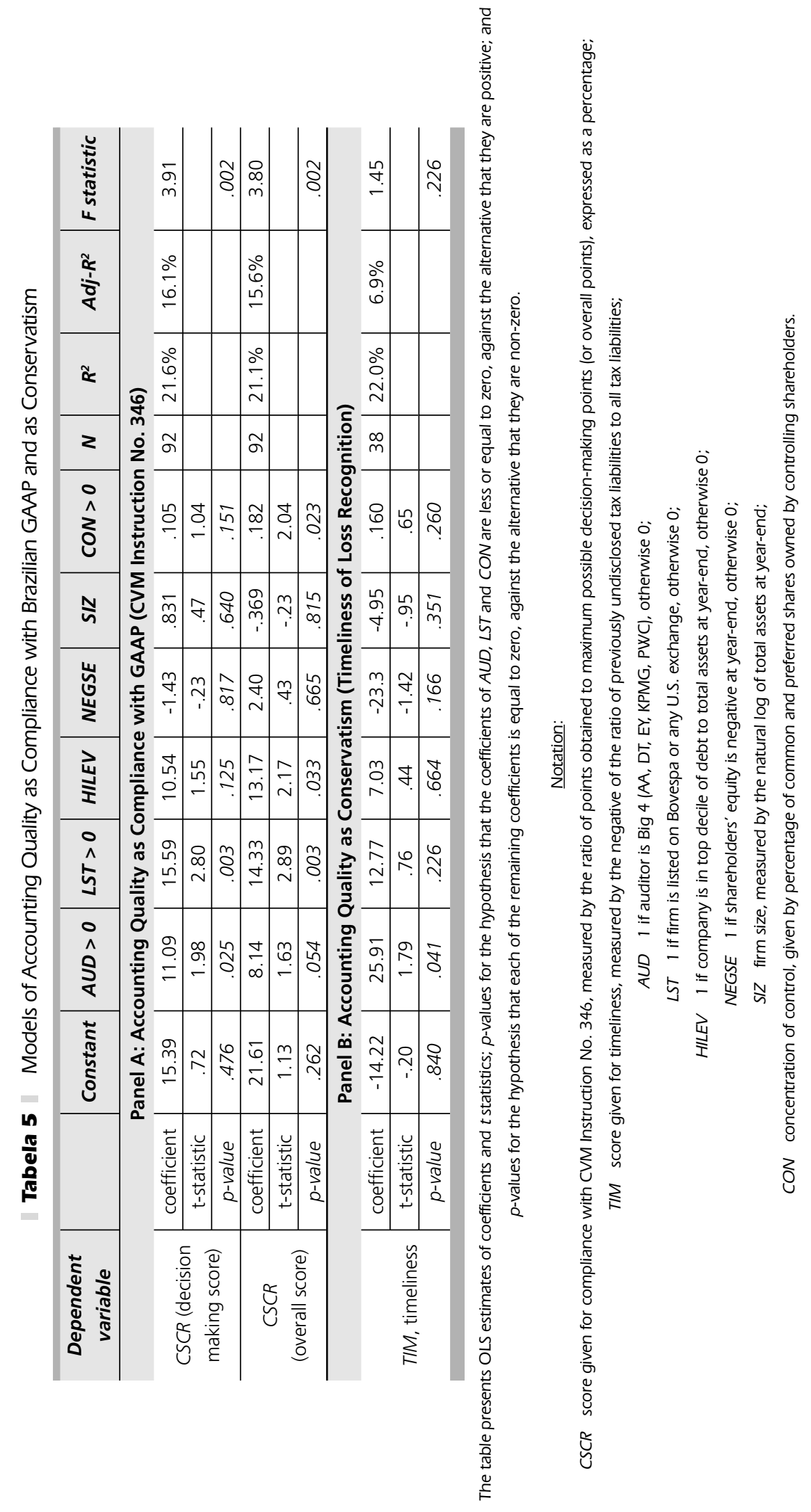


\section{References}

AHARONY, J., DOTAN, A. A Comparative Analysis of Auditor, Manager and Financial Analyst Interpretations of SFAS 5 Disclosure Guidelines. Journal of Business, Finance and Accounting. 31 (3-4): p. 475-504, 2004.

BECKER, C. L., DeFOND, M. L., JIAMBALVO, J., Subramanyam, K. R. The Effect of Audit Quality on Earnings Management. Contemporary Accounting Research. 15 (1): p. 1-24, 1998.

BOTOSAN, C. Disclosure Level and the Cost of Equity Capital. The Accounting Review. 72 (3): p. 323-349, 1997.

DECHOW, P. M., SLOAN, R. G. \& SWEENEY, A. P. Detecting Earnings Management. The Accounting Review. 70 (2): p. 193-225, 1995.

DeFOND, M. L., JIAMBALVO, J. Incidence and Circumstances of Accounting Errors. The Accounting Review. 66 (3): p. 643-655, 1991. and 176, January 1994.

. Debt covenant violation and manipulation of accruals. Journal of Accounting and Economics. 17: p. 145-

ERNST \& YOUNG. Substance over Form in Latin America: Myth or Reality. Latin American Business Centre of E\&Y in Europe, 2002.

FRANCIS, J., LaFOND, R., \& OLSSON, P. M. Costs of Equity and Earnings Attributes. The Accounting Review. 79 (4): p. 967-1010, 2004.

HOLTHAUSEN, R. W. Testing the Relative Power of Accounting Standards versus Incentives and Other Institutional Features to Influence the Outcome of Financial Reporting in an International Setting. Journal of Accounting and Economics. 36: p. 271-283, 2003.

HRIBAR, P., JENKINS, N. T. The Effect of Accounting Restatements on Earnings Revisions and the Estimated Cost of Capital. Review of Accounting Studies. 9: p. 337-356, 2004.

HUNG, M. Accounting Standards and Value Relevance of Financial Statements: An International Analysis. Journal of Accounting and Economics. 30: p. 401-420, 2001.

JONES, J. J. Earnings Management During Import Relief Investigations. Journal of Accounting Research. 29 (2): p. 193-228, 1991.

KPMG. Comparações entre Práticas Contábeis. 2nd Edition. Department of Professional Practices, Brazil, 2001.

La PORTA, R., LOPEZ-DE-SILANES, F., SHLEIFER, A. \& VISHNY, R. W. Law and Finance. Journal of Political Economy. 106 (6): p. $1113-$ $1155,1998$.

PATEL, S. A., BALIC, A., \& BWAKIRA, L. Measuring Transparency and Disclosure at Firm-Level in Emerging Markets. Standard \& Poor's. New York, May 2002.

RAGHUNANDAN, K., GRIMLUND, R., \& SCHEPANSKI, A. Auditor Evaluation of Loss Contingencies. Contemporary Accounting Research. Spring: p. 549-569, 1991.

REIMERS, J. L. Additional Evidence on the Need for Disclosure Reform. Accounting Horizons. March: p. 36-41, 1992.

RICHARDSON, A., WELKER, M. Social Disclosure, Financial Disclosure and the Cost of Equity Capital. Accounting, Organizations and Society. 26: p. 597-616, 2001.

\section{NOTE - address of the author}

Seatlle University

$901-12^{\text {th }}$ Ave., P.O. Box 222000

Seatlle, WA - USA

98122-1090 